JURNAL ILMIAH MUQODDIMAH

Jurnal Ilmu Sosial, Politik, dan Humaniora

\title{
ANALISIS STRATEGIS PEMKO MEDAN DALAM MELAKUKAN SISTEM PENGELOLAAN SAMPAH BERBASIS OPEN DUMPING MENJADI SANITARY LANDFILL
}

\author{
Jehan Ridho Izharsyah \\ Fakultas IImu Sosial dan IImu Politik \\ Universitas Muhamadiyah Sumatera Utara \\ jehanridho@umsu.ac.id
}

\begin{abstract}
ABSTRAK
Sampah sampai saat ini masih menjadi tantangan terbesar hampir diseluruh kotakota besar di dunia. tantangan ini tentunya sebagai tolok ukur kota-kota tersebut layak tidaknya menjadi building town. permasalahan sampah tidak ada henti-hentinya dibahas di dunia terutama di indonesia khusunya kota medan. hal tersebut dikarenakan sampah berkaitan dengan reaktif aktifitas keseharian manusia serta budaya keseharian masyarakat. Tujuan penelitian ini adalah untuk mengetahui bagaimana analisis strategis Pemko Medan dalam melakukan sistem pengelolaan sampah berbasis open dumping menjadi sanitary landfil Penelitian ini menggunakan metode penelitian deskriptif kualitatif. Penelitian yang dilakukan dengan studi lapangan, Wawancara dan Dokumentasi dengan beberapa kelompok kepentingan. Hasil Penelitian menunjukan bahwa Pemerintah Kota Medan kembali kepada Undang-undang Nomor. 18 tahun 2008 Tentang Pengelolaan Sampah yang menuntut harus menyusun langkah strategis setelah masa ketetapan di dalam Undang-undang tersebut berakhir. Pengalihan sistem Open Dumping menjadi Sanitary Landfill dimulai dari Pewadahan, Pemilahan, Pengumpulan, pengangkutan dan pembuangan akhir. Kota Medan mulai menerapkan langkah-langkah tersebut Walaupun TPA Terjun masih digunakan dan TPA Namo Bintang masih dalam tahap pengembangan. Sistem Zonasi TPA Namo Bintang Kecamatan Tuntungan pada Pengelolaan Sanitary Landfill ini jauh dari permukiman mengingat untuk mengutamakan Aspek Lingkungan sesuai arahan Kementrian Lingkungan Hidup Republik Indonesia.
\end{abstract}

Kata Kunci: Manajemen, Pengelolaan Sampah, Sanitary Landfill

\begin{abstract}
Garbage is still the biggest challenge in almost all major cities in the world. This challenge is certainly a benchmark for those cities that are worthy of building town. the problem of rubbish is unrelentingly discussed in the world especially in Indonesia especially Medan city. that is because waste is related to the reactive human daily activities and the daily culture of the community. The purpose of this study was to find out how the Medan City Government's strategic analysis in carrying out an open dumping-based waste management system into a sanitary landfill. This study used a descriptive qualitative research method. Research carried out by field studies, interviews and documentation with several interest groups. Research results show that the Medan City Government returned to Law Number. 18 of 2008 concerning Waste Management which requires must compile strategic steps after the stipulation period in the Act has ended. The transfer of the Open Dumping system to a Sanitary
\end{abstract}


JURNAL ILMIAH MUQODDIMAH

Jurnal Ilmu Sosial, Politik, dan Humaniora

Landfill starts with Reservation, Separation, Collection, transport and final disposal. The city of Medan has begun to implement these steps even though the TPA of the Falls is still being used and the Namo Bintang TPA is still under development. Namo Bintang Landfill Zoning System in Tuntung Subdistrict on the Sanitary Landfill Management is far from the settlement considering to prioritize the Environmental Aspects according to the direction of the Ministry of Environment of the Republic of Indonesia.

Keywords: Management, Waste Management, Sanitary Landfill

\section{PENDAHULUAN}

Sampah sampai saat ini masih menjadi tantangan terbesar hampir diseluruh kota-kota besar di dunia. Tantangan ini tentunya sebagai tolok ukur kota-kota tersebut layak tidaknya menjadi building Town. Permasalahan sampah tidak ada henti-hentinya dibahas di dunia terutama di Indonesia. Hal tersebut dikarenakan sampah berkaitan dengan reaktif aktifitas keseharian manusia serta budaya keseharian masyarakat tersebut.

Menghitung jumlah sampah sangat erat kaitannya dengan jumlah penduduk di Indonesia. Dari data penelitian yang dihimpun hamper rata-rata masyarakat menghasilkan $0,5 \mathrm{~kg}$ sampah perhari. Sedangkan di kota besar seperti Jakarta sendiri menghasilkan $1 \mathrm{~kg}$ sampah per hari. Sebenarnya terjadi perbedaan setiap daerah tergantung dari aktifitas yang dilakukan masyarakat di daerah tersebut. Dengan asumsi semakin besar pertumbuhan penduduk semakin banyak jumlah kebutuhan hidup maka semakin banyak aktivitas dan sampah yang dihasilkan.

Hampir saat ini produksi sampah tidak sebanding dengan jumlah rata-rata masyarakat di Indonesia. Malah kuota sampah lebih tinggi pertahunnya dengan prediksi yang telah di proyeksikan. Menurut data yang telah diperoleh dari SIPSN (Sistem Informasi Pengelolaan Sampah Nasional) Kementrian Lingkungan Hidup dan Kehutanan Republik Indonesia pada saat ini Indonesia telah menghasilkan

Volume 4, Nomor 2, Agustus 2020 menghasilkan sampah sekitar 66 - 67 juta ton sampah pada tahun 2019. Jumlah ini lebih tinggi dibandingkan jumlah sampah per tahunnya yang mencapai 64 juta ton. Sebab diproyeksikan pada tahun 2020 produksi sampai di Indonesia akan semakin bertambah hingga 80-100 juta ton.

Kota Medan merupakan salah satu kota besar di Indonesia dengan padatnya aktifitas masyarakat setiap hari. Kehadiran masalah sampah di Kota Medan bukan menjadi masalah yang baru-baru saja hadir, akan tetapi Medan merupakan salah satu Kota penghasil sampah terbesar di Indonesia.

Hal ini dilihat dari peningkatan jumlah data pesampahan di Kota Medan di Mulai tahun 2008-2013, 2013-2018 dan diproyeksikan 5 tahun kedepan. Menurut data Badan Lingkungan Hidup Kota Medan tahun 2008-2009 produksi sampah sebesar 33,85 ton. Kemudian ditahun berikutnya 2009-2010 meningkat sebesar 677, 89 ton. Pada tahun 2010-2011 menurun sebesar 22,6556 ton, kemudian ditahun berikutnya meningkat sebesar 270,3306 ton, kemudian di tahun 20122013 sampai setiap hari berkisar 1.700 ton kemudian rentan waktu tahun 2015 mencapai 1.900 ton perhari. Dengan data tersebut, berarti setiap bulan masyarakat Kota Medan menghasilkan 44.000 ton sampah perbulan.

Pemerintah Kota Medan sendiri telah berusaha menyusun sistem tata kelola persampahan. Baik itu dengan 
JURNAL ILMIAH MUQODDIMAH

Jurnal Ilmu Sosial, Politik, dan Humaniora

sistemik maupun manual sekalipun. Pada tahun 2008 Pemerintah Kota Medan melakukan sistem tata kelola persampahan dengan mengadakan Tempat Pembuangan Akhir (TPA) sampah di Kota Medan. Dalam UndangUndang Nomor 18 Tahun 2008 Tentang Pengelolaan Sampah, tersebut pada pasal 44 ayat 2 menyebutkan pemerintah daerah harus menutup tempat pembuangan akhir sampah dengan menggunakan sistem pembuangan terbuka (open dumping) paling lama 5 (lima) tahun terhitung sejak berlakunya undangundang tersebut.

Apabila terhitung dengan terimplementasinya Undang-Undang Nomor 18 tahun 2008 Tentang Pengelolaan Sampah sampai kini sudah berusia lebih dari 5 tahun dan sudah berjalan 11-12 tahun sekarang . Artinya, TPA sistem open dumping tidak boleh dilakukan lagi. Banyak Hal yang harus diperhatikan terutama untuk lingkungan dan dampak pencemaran dan tentunya ini juga menyangkut dengan AMDAL.

Kajian penelitian yang relevan dalam penelitian ini pernah dilakukan oleh Dewita Sari, Syafruddin Ritonga yang berjudul Peran Dinas Kebersihan Dalam Pengelolaan Sampah Rumah Tangga di TPA Terjun Kecamatan Medan Marelan. Hasil penelitian ini adalah pelaksanaan peran dinas kebersihan dalam pengelolaan sampah rumah tangga di TPA Terjun Kecamatan medan marelan belum maksimal dan ada beberapa kekurangan dari segi eksternal misalnya, alokasi dana yang di berikan Pemerintah pusat sangat minim dikarenakan biaya banyak terpakai untuk mengganti alat-alat yang sudah tua seperti excavator dan buldozer maupun truk sampah

Maka dari itu, penelitian ini akan melihat "Bagaimana Strategis Pemerintah Kota Medan dalam melakukan Sistem Pengelolaan Sampah Berbasis Open Dumping Menjadi Sanitary Landfill"?

\section{METODE}

Penelitian ini menggunakan metode penelitian Deskriptif kualitatif. Penelitian yang dilakukan dengan studi lapangan, Wawancara dan Dokumentasi dengan beberapa kelompok kepentingan seperti: Badan Lingkungan Hidup dan Kehutanan Kota Medan, Dinas Kebersihan Kota Medan dan Badan Perencanaan dan Pembangunan Daerah Kota Medan. Kemudian melakukan studi lapangan ke Tempat Pembuangan Akhir (TPA) Terjun jalan Marelan Raya Pasar v Rengas Pulau, Kec. Medan Marelan, Kota Medan, Sumatera Utara 20255 dan TPA Namo Bintang Kecamatan Deli Serdang.

\section{HASIL DAN PEMBAHASAN}

Menyikapi pelaksanaan dari Undang-Undang Nomor 18 tahun 2008 Tentang Pengelolaan Sampah, maka pemerintah Kota Medan sudah harus menyusun dan merumuskan langkah strategis guna mengatasi permasalahan sampah di Kota Medan. Maka ada beberapa tahapan yang dilakukan oleh pemerintah Kota Medan. Hal ini juga berkaitan dengan pelaksanaan Rencana Tata Ruang Wilayah yang disusun oleh Pemerintah Kota Medan. Oleh karena itu pertama sekali dalam penelitian ini untuk melihat langkah strategisnya ialah melihat tahapan tahapan perencanaan, pengaturan dan pengawasan.

\section{Aspek Perencanaan}

Dalam Upaya menginterpretasikan kebutuhan akan permasalahan sampah. Pemerintah Kota Medan telah dibantu oleh Bappeda dalam merumuskan RTRW Kota Medan. Rencana Tata Ruang Wilayah disusun untuk dapat memberikan gambaran pemanfaatan tuang wilayah kota hingga 20 (dua puluh tahun). Subbidang Tata ruang Bappeda dan Dinas Kebersihan lingkungan hidup membuat sistemik program dan integrasi program untuk penanggulangan masalah 
persampahan di Kota Medan. Yaitu dengan penyediaan ruang/tempat penampungan sampah akhir (TPA).

Sistem penyediaan ruang/tempat penampungan sampah tentunya harus memperhatikan sistem pengelolaannya. Sistem pengelolaan persampahan adalah system yang dirancang, disusun serta dikembangkan untuk meningkatkan dan tentunya memperhatikan aspek lingkungan khususnya kesehatan dan kualitas lingkungan yang bersih. Maka pola perencanaan yang dapat diperoleh adalah:

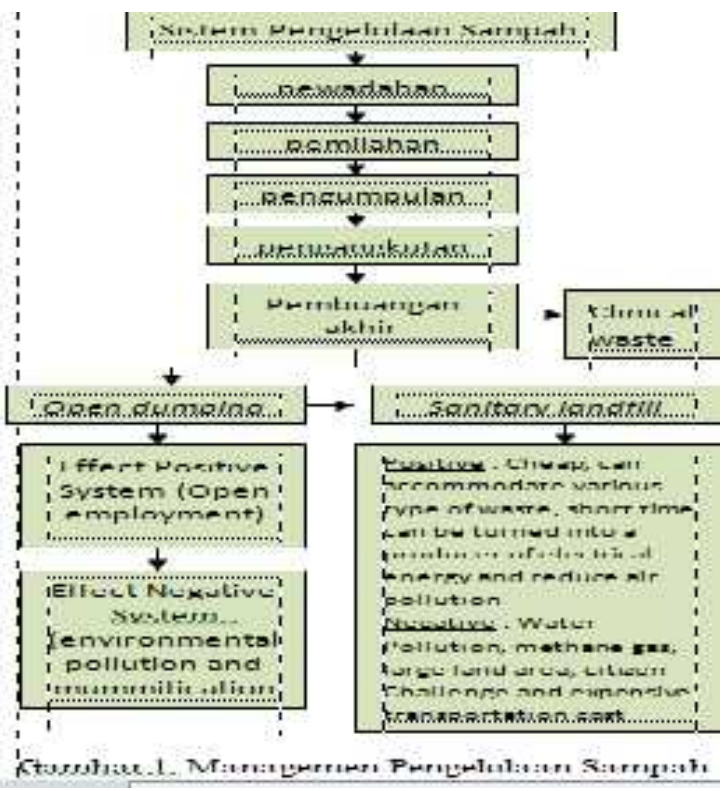

Dari gambar diatas, dapat dijelaskan sistemik yang digunakan pemerintah Kota Medan dalam melakukan manajemen pengelolaan Sampah dengan mempertimbangkan implementasi Undang-Undang Nomor 18 tahun 2008 Tentang Pengelolaan Sampah. Maka tahapan-tahapan yang dilakukan adalah sebagai berikut :

a. Pewadahan

Pada tahap ini adalah sosialisasi awal pada tahapan lingkungan, dalam konteks prosedur bahwa kepala lingkungan bertanggungjawab untuk menghimbau warga lingkungan dengan penggunaan wadah sampah dan menyediahkan pewadahaan dilingkungan masyarakat. Maka, yang harus diperlukan adalah kepala lingkungan dapat menyediahkan tempat pembuangan sampah.

b. Pemilahan

Dalam Tahap ini disamping pewadahan yang telah disediahkan oleh kepala lingkungan, masyarakat juga diwajibkan untuk memilah jenis sampahnya masing-masing baik itu organik dan non-organik. Dalam tahapan ini tahapan akan semakin tinggi dengan mengikutsertakan Lurah untuk memotovasi masyarakat dalam tahap pemilahan ini. Karena dalam konteks ekonomis dan non ekonomis melihat volume sampah yang setiap hari terus bertambah fase ini dapat digunakan dengan melihat sebahagian besar sampah masih bisa dimanfaatkan untuk keperluan tanaman, kreativitas dan lain-lain.

c. Pengumpulan

Dalam Tahap ini perlu diperhatikan terutama kepada petugas kebersihan dan dibantu oleh petugas lingkungan yang ada di kelurahan. Pemerintah Kota Medan membagi menjadi dua pola dalam pengumpulan pola ini diantaranya:

1. Pola Pengumpulan Langsung (House to House Collection) dalam tahapan ini sampah dikumpul dengan truk sampah dan kemudian dibuang ke TPA.

2. Pola Pengumpulan tidak Langsung : dalam tahapan ini proses pengumpulan sampah dengan menggunakan becak/gerobak sampah dan kemudian dipindahkan terlebih dahulu ke Tempat Penampungan Sementara (TPS) 
Pada fase ini lurah bertanggungjawab dalam mensosialisasikan jadwal waktu pembuangan/pengumpulan sampah.

d. Pengangkutan

Dalam tahap ini, Pemerintah Kota Medan melakukan sistem dengan dua pola yaitu :

1. Pola Pengangkutan Langsung : pengangkutan digunakan menggunakan truk sampah secara langsung dari sumber sampah dan kemudian diangkat langsung ke TPA.

2. Pola Pengangkutan Tidak Langsung : pengangkutan ini dilakukan dengan truk sampah dengan cara mengangkut sampah yang telah terkumpul/tertumpuk di TPS dan kemudian diangkut ke TPA.

Pada Fase ini Camat harus berperan aktif dengan petugas kebersihan Kecamatan serta melakukan koordinasi dengan Dinas Kebersihan mengenai jadwal pengangkutan Sampah di TPA.

a. PembuanganAkhir

Pada tahap ini lah proses yang menjadi tolak ukur dalam system pengelolaan sampah pada dasarnya. Karena, pembuangan akhir ini terkadang masih menjadi tugas besar sebahagian kota-kota di Indonesia. Dalam Rencana Tata Ruang Wilayah Kota Medan, Pemerintah Kota Medan sendiri telah merencanakan system pembuangan sampah yang dulu itu adalah Open Dumping menjadi sanitary Landfill.

b. Open Dumping

Open Dumping merupakan cara yang dilakukan dengan sistem yang sangat sederhana dengan membuang sampah pada legokan atau cekungan tanpa menggunakan tanah sebagai penutup sampah. System ini pada dasarnya tingkat keefektifannya sampai 5 tahun sesuai dengan Undang-Undang Nomor 18 tahun
2008 Tentang Pengelolaan Sampah. Dampak lingkungannya sangat besar dalam mencemari lingkungan baik pencemaran air tanah oleh Leachate (air sampah yang dapat menyerap kedalam tanah) lalat, kecoa tikus tanah dan lain-lain. Maka dari itu pemerintah Kota Medan mengalihkan system Pengolahan sampah Open Dumping menjadi sanitary Landfill.

c. Sanitary Landfill

Sanitary Landfill merupakan sistem pembuangan sampah yang dilakukan dengan cara sampah ditimbun di TPA sampah tersebut sudah di filter secara teknis menurut jenis sampahnya. Dalam sistem ini penggunaan alat berat sangat dibutuhkan seperti bulldozer maupun track loader untuk memdatkan sampah tersebut kemudian ditutup dengan tanah sebagai lapisan penutup setiap hari pada setiap akhir kegiatan.

Dalam pembuangan akhir ini juga ada sampah yang dikelola sendiri dalam sistemnya, yaitu Clinical waste. System ini juga dilakukan oleh rumah sakit dalam pengelolaannya. Yaitu pemusnahan sampah medis melalui Incenerator Medis.

\section{Aktualisasi sistem pengelolaan Sanitary Landfill.}

Dalam sistem ini, pemerintah Kota Medan yang meninggalkan sistem Open Dumping sebenarnya memiliki dampak positif dan negatif. Dampak Positif dari sistem Open Dumping adalah membuka lapangan kerja/kesempatan bagi pemulung di TPA. Maka dengan beralihnya ke sistem Sanitary Landfill para pemulung menjajaki sampah pada tahap pewadahan dilingkungan-lingkungan warga. Karena sistem Sanitary Landfill langsung menggunakan alat berat ketika sampah datang dari TPA dan langsung dipadatkan untuk tidak menimbulkan pencemaran lingkungan. Maka kesempatan Pemulung juga hampir tidak ada di TPA dengan sistem Sanitary 
Landfill ini. Sedangkan dapak negatif sistem dumping tentunya sangat berbahaya terhadap lingkungan baik pencemaran air, tanah dan udara)

Sistem Pengelolaan Sanitary Landfill merupakan sistem yang banyak digunakan di Indonesia. Karena, sistem tersebut dilakukan dengan menumpuk sampah di lokasi cekung, memadatkan dan kemudian menimbunnya dengan tanah. Sistem Zonasi TPA pada Pengelolaan Sanitary Landfill ini harus jauh dari pemukiman karena untuk menghindari masalah sosial seperti AMDAL dan pencemaran lainnya. Mak dari itu pemerintah Kota Medan Menzonasikan kawasan Sistem Pengelolaan Sanitary Landfill ini di TPA Namo Bintang Kecamatan Medan Tuntungan. Berikut ini merupakan TPA yang sebelumnya digunakan Pemerinyah Kota Medan dalam pengelolaan sampah menggunakan sistem Open Dumping

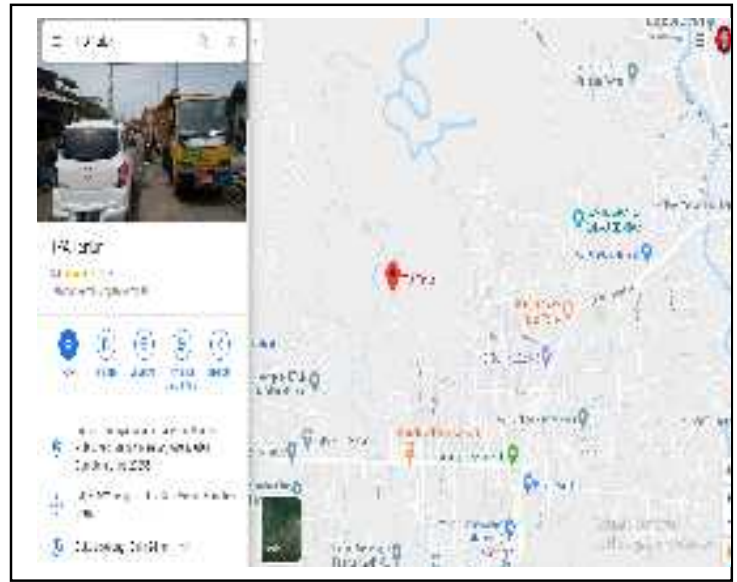

Gambar.1.2 Tempat Pembuangan Akhir Terjun

Dalam mengaktualisasikan sistem Sanitary Landfill pemerintah Kota Medan juga harus memperhatikan elemenelemen penting yang telah di analisis oleh Kementrian Lingkungan Hidup Republik Indonesia diantaranya :

1. Lining System : atau bagian terbawah yang bersentuhan dengan tanah. Bagian ini biasa terbuat dari campuran tanah dan bentonite agar cairan dari pembusukan sampah tidak akan merembes ke dalam tanah dan mencemari air tanah.

2. Leachate Collection System : leachate atau lindi adalah cairan yang keluar dari pembusukan sampah dan terkontaminasi oleh berbagai bahan kimia atau bakteri. Oleh karena itu tidak boleh merembes ke dalam tanah. Selain lining sistem di bagian bawah, di atasnya akan dibuatkan leachate collection sistem untuk mengumpulkan lindi agar tidak menggenang dan pada akhirnya merembes ke dalam tanah.

3. Cover or cap system: gunanya untuk mengurangi air, seperti hujan yang masuk ke dalam tumpukan sampah agar jumlah leachate atau lindi tidak semakin banyak.

4. Sistem Ventilasi : pembusukan sampah akan menghasilkan gas metana dan konsentrasi gas tanpa bisa disalurkan beresiko menimbulkan ledakan

5. Sistem Monitor: untuk mengawasi dan memberi peringatan dini jika terjadi kebocoran dalam sistem yang berbahaya bagi manusia dan lingkungan.

Elemen-elemen sistem diatas merupakan dasar yang harus dipahami oleh Pemerintah Kota Medan dalam mengaktualisasikan sistem Sanitary Landfill karena kita juga harus mengutamakan aspek biota kehidupan micro tanah dan dampak lingkungan yang ditimbulkan. Pemerintah Kota Medan juga harus mengetahui dampak positif dan negatif menggunakan Sistem Sanitary Landfill. Dampak positifnya diantaranya :

1. Murah : konteks murah dalam hal ini adalah tidak memerlukan investasi besar hanya Pemerintah Kota Medan harus menyediahkan Lahan yang luas dan jauh dari Pemukiman. 


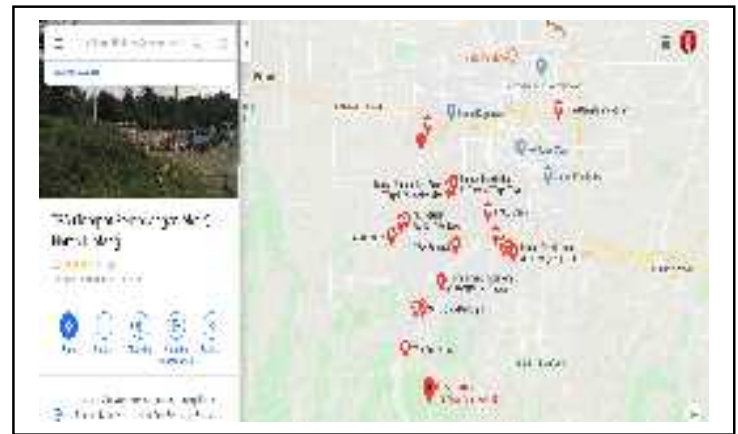

Gambar.1.3 Tempat Pembuangan Akhir Namo Bintang Tuntungan

TPA Namo Bintang sebenarnya telah beroperasi sejak juli 1984, yang luasnya 16 hektar Namun TPA ini telah ditutup Walikota Medan berdasarkan keputusan Walikota Medan Nomor 658.1/317.K/III/2013 tanggal $19 \quad$ Februari 2013. Dikarenakan TPA Namu Bintang belum memenuhi standar Kementrian Lingkungan Hidup Republik Indonesia terutama untuk dampak lingkungan dan kualitas tanah.

2. Dapat menampung berbagai jenis sampah : dalam hal ini sistem Sanitary Landfill dapat dipahami sebagai sistem pengelolaan semua jenis sampah karena memasukkan sampah kedalam cekungan, memadatkan dan menimbun tanah diatasnya.

3. Dapat disiapkan dalam waktu yang singkat : sistem ini tidak memerlukan waktu lama dari pewadahan sampai pembuangan akhir atau sementara

4. Dapat dirubah menjadi penghasil energi listrik karena sampah akan mengeluarkan gas metana yang bisa dijadikan bahan bakar penggerak turbin.

5. Mengurangi polusi udara karena sampah-sampah tersebut berada di dalam tanah

Kemudian untuk dampak negatif.

Antara lain :

1. Pencemaran air: sampah-sampah, terutama bahan organik atau kimia

Volume 4, Nomor 2, Agustus 2020 sering menghasilkan cairan yang dapat merembes ke dalam tanah dan bisa mencemari tanah dan air.

2. Gas metana yang keluar dari proses pembusukan sampah, jika tidak dialirkan dapat menimbulkan bahaya ledakan seperti pernah terjadi di TPA.

3. Membutuhkan lahan yang luas maka dari itu perencanaan dan strategisnya dilakukan di TPA Namo Bintang di Tuntungan daerah yang belum padat penduduknya.

4. Mendapat tentangan dari warga : pada saat sekarang ini pemerintah Kota Medan memang belum mendapatkan tantangan warga. Akan tetapi mengingat kepadatan penduduk semakin tinggi di khawatirkan aktivitas masyarakat akan banyak sampai ke lokasi TPA.

5. Butuh biaya transportasi yang mahal dan juga menghasilkan polusi udara

\section{KESIMPULAN}

Berdasarkan hasil pernyataan diatas kesimpulan dari penelitian ini adalah sebagai berikut :

1. Aspek Perencanaan: aspek ini merupakan bagian dasar dari rencana strategis yang menjelaskan bagaimana pemerintah Kota Medan kembali kepada Undang-Undang Nomor. 18 tahun 2008 Tentang Pengelolaan Sampah yang menuntut harus menyusun langkah strategis setelah masa ketetapan di dalam Undang-undang tersebut berakhir. Pengalihan sistem Open Dumping menjadi sanitary Landfill merupakan langkah yang banyak dilakukan oleh Kota- kota besar di Indonesia yang dimulai dari Pewadahan, Pemilahan, Pengumpulan, pengangkutan dan pembuangan akhir. Kota Medan mulai menerapkan langkah-langkah tersebut.

2. Aktualisasi: Pengalihan sistem Open Dumping kepada sanitary Landfill 
banyak tantangan dan tugas besar pemerintah Kota Medan. Ada dampak positif dan negatif. Sistem Zonasi TPA pada Pengelolaan Sanitary Landfill ini harus jauh dari pemukiman karena untuk menghindari masalah sosial seperti AMDAL dan pencemaran lainnya. Terutama penyediaan lahan yang cocok dan tidak mengganggu aktifitas kehidupan masyarakat.

\section{SARAN}

1. Pemerintah Kota Medan melakukan penguatan terhadap sistem pengelolaan persampahan di Kota Medan. Mengingat sistem sanitary Landfill ini perlu banyak kajian maka perlu adanya integrasi terhadap seluruh kelompok kepentingan antara lain : Government, Privat Civil Society, praktisi lingkungan dan praktisi kebijakan daerah.

2. Pemerintah Kota Medan sudah saatnya mengembangkan tata ruang dengan penyediaan TPA dengan memperhatikan kesesuaian lahan, genesis tanah dan klasifikasi tanah. Mengingat TPA Namo Bintang pernah ditutup dikarenakan belum memenuhi standar elemen sistem yang ditetapkan oleh Kementrian Lingkungan Hidup Republik Indonesia.

3. Melakukan monitoring dan Evaluasi terhadap sistem yang berlaku sesuai dengan Standar Operasional Prosedur yang dimulai dari pewadahan hingga pembuangan akhir.

\section{DAFTAR PUSTAKA}

Adisasmita, Raharjo. 2011. Manajemen Pemerintah Daerah. Yogyakarta. Graha IImu.

Badan Pusat Statistik Kota Medan (2019), Kota Medan Dalam Angka

Badan Lingkungan Hidup Kota Medan, 2017. Pengolahan Persampahan, Modul

Volume 4, Nomor 2, Agustus 2020
Bungin, Burhan. 2011. Metodologi Penelitian Kuantitatif. Jakarta. Kencana.

Dinas Kebersihan Kota Medan, (2017) , Sistem Pengelolaan sampah Kota Medan.

Damanhuri, Enri, 2003, "Permasalahan dan Alternatif Teknologi Permasalahan Sampah Kota di Indonesia", Prosiding Seminar Teknologi Untuk Negeri, Vol.I. Hal.394-400

Dunn W. N. Analisis Kebijakan Publik, 2003, Hanindita Graha Widya, Yogyakarta.

Faizah, 2008, Pengelolaan Sampah Rumah Tangga Berbasis Masyarakat (Studi Kasus di Kota Yogyakarta), Tesis, Program Magister IImu Lingkungan, Undip, Semarang.

Harian Medan Bisnis, 2015, Pemko Medan Buka Lagi TPA Namo Bintang.

http://www.medanbisnisdaily.com/ news $/ \mathrm{read} /$ ? id $=194256$

Hartono, Edi 2006, Peningkatan Pelayanan Pengelolaan Sampah di Kota Brebes Melalui Peningkatan Kemampuan Pembiayaan, Tesis, Program Studi Magister Teknik Perencanan Wilayah dan Kota, Undip, Semarang.

Hidayat, Taufik, 2004. Identifikasi Preferensi Masyarakat dalam Pengelolaan Persampahan Permukiman di Kecamatan Harjamukti, Kota Cirebon, Tugas Akhir tidak diterbitkan, Program Studi Perencanaan Wilayah dan Kota, Fakultas Teknik Undip, Semarang.

Irman, 2005, Evaluasi Peran Serta Masyarakat dalam Pelaksanaan Sistem Teknik Operasional Pengelolaan Sampah Di Kota Padang, Tesis, Program Studi 
Magister Perencanan Wilayah dan Kota, Undip, Semarang.

JICA, 2002, Draf Naskah Akademis Rancangan Perundang-undangan Pengelolaan Sampah,

Mirnawati, 2017, Analisis Kinerja Pengolahan Sampah di Kota Metro (Studi di Tempat Pembuangan Akhir Sampah (TPAS) Kota Metro Tahun 2015.Tesis, Magister IImu Administrasi,Unila, Bandar Lampung.

Nugroho, D. Riant, 2003, Kebijakan Publik : Formulasi, Implementasi dan Evaluasi, Penerbit Elex Media Komputindo, Jakarta.

Pemerintah Kota Medan (2016), Rencana Strategis Kota Medan 2016-2021.

Peraturan Daerah Kota Medan, Keputusan Walikota Medan Nomor 658.1/317.K/III/2013 tanggal 19 Februari 2013 Tentang TPA Namu Bintang.

PKP2AI, LAN,2004, Kajian Tentang Pengelolaan Bersama (Joint Manajement) Pelayanan Persampahan di Perkotaan.

Rukmana, Nana et,al. 1993, Manajemen Pembangunan Prasarana Perkotaan, Pustaka LP3ES, Jakarta.

Sari, Dewita. 2016. Peran Dinas Kebersihan Dalam Pengelolaan Sampah Rumah Tangga di TPA Terjun Kecamatan Medan Marelan. Medan, Publikauma

Undang-Undang Nomor 18 tahun 2008 Tentang Pengelolaan Sampah 